\title{
SOM E VERDADE: PESQUISA INTERDISCIPLINAR EM SOM E COMPOSIÇÃO MUSICAL
}

\section{SOUND AND TRUTH: AN INTERDISCIPLINARY RESEARCH IN SOUND AND MUSICAL COMPOSITION}

\author{
Paulo C. Chagas \\ Universidade da Califórnia \\ paulo.chagas@ucr.edu
}

\section{Resumo}

Este artigo examina alguns aspectos da minha recente pesquisa interdisciplinar em fenomenologia do som e composição musical, a qual explora questões filosóficas, culturais, sociais e políticas, e estabelece um diálogo subjetivo e multipolar com a tecnologia. As novas formas de escuta mediadas tecnologicamente, os novos processos de produção, manipulação e transformação do som ocupam nossos espaços físicos e existenciais. Wittgenstein sugere que o som é apenas a superfície da música e que a obra musical esconde algo mais profundo que dificilmente pode ser descrito por modelos lógico-filosóficos ou teorias científicas. Como ilustração do meu trabalho de composição, discuto algumas ideias da minha obra A Celadeira (2014), oratório digital que tematiza a minha experiência de tortura durante a ditadura militar no Brasil e reflete sobre o conceito de absurdo da filosofia existencial de Camus. A fenomenologia da consciência do tempo de Husserl respalda minha pesquisa em fenomenologia do som focada na música eletroacústica. Com base nas discussões de Kuhn, introduzo a ideia um paradigma eletroacústico como matriz disciplinar da música contemporânea. Examino o conceito de aparelho, sob os pontos de vista de Agamben e Flusser, como uma noção chave para se compreender a atual fase do capitalismo e as estruturas de comunicação e criatividade da sociedade cibernética. Finalmente, discuto a visão de que a verdade é a essência da arte, a partir de Heidegger. A arte nos ajuda a desenvolver uma nova compreensão do ser, que se distancia da experiência estética moderna de um objeto de arte para uma abordagem pós-moderna da obra de arte. A universidade é um ambiente privilegiado para observar conexões interdisciplinares entre disciplinas artísticas e as interseções 
entre arte, tecnologia e sociedade, superando a interpretação e disseminação de conhecimentos científicos e humanísticos e oferecendo múltiplas perspectivas para o avanço da pesquisa e do pensamento crítico.

Palavras-chave: Som; Tecnologia; Tortura; Paradigma; Aparelho.

\section{Abstract}

This article examines some aspects my recent interdisciplinary research on sound phenomenology and musical composition, which explores philosophical, cultural, social, and political issues and engage a subjective and multipolar dialog with technology. New forms of technologically mediated listening, new processes of producing, manipulating, and transforming sound shape our lives and occupy our physical and existential living spaces. Wittgenstein suggests that sound is only the surface of music and that the musical work conceals something more profound that can hardly be described by logical-philosophical models or scientific theories. As an illustration of my compositional work, I discuss some ideas of my work The Refrigerator (20|4), digital oratorio that thematizes my experience of torture during the military dictatorship in Brazil and reflects on Camus existential philosophical concept of absurdity. Husserl's phenomenology of time consciousness supports my research on sound phenomenology focused on electroacoustic music. Based on Kuhn's concept of scientific paradigm, I draft the idea of an electroacoustic paradigm as disciplinary matrix of contemporary music. I examine the concept of apparatus from the points of view of Agamben and Flusser as a key notion for understanding the current phase of capitalism and the structures of communication and creativity of the cybernetic society. Finally, I discuss Heidegger's view of truth as the essence of art. Art help us to develop a new understanding of the being that moves from a modern aesthetic experience of an art object to a post-modern approach to the work of art. The university is a privileged environment to observe interdisciplinary connections between artistic disciplines and the intersections between art, technology, and society. The university's role is not only to interpret and spread scientific and humanistic knowledge but to embrace cultural diversity by offering multiple perspectives for advancing research and critical thinking.

Keywords: Sound; Technology; Torture; Paradigm; Apparatus.

\section{8}

REV. TULHA, RIBEIRÃO PRETO, v. 5, n. 2, pp. 107-132, jul.-dez. 2019 


\section{Introdução: pós-história, evolução, consciência, ética e estética, conhecimento e entendimento}

Costaria de iniciar este texto abordando algumas questões filosóficas que orientam a minha pesquisa. Falarei sobre os conceitos de pós-história, evolução, consciência humana, ética e estética. Em seguida apresentarei dois exemplos da pesquisa recente que desenvolvo na Universidade da Califórnia, Riverside, a primeira no campo da composição, e a segunda no campo da fenomenologia do som.

Estamos vivendo um período de grandes turbulências e profundas transformações. $\bigcirc$ processo de globalização desperta a consciência da humanidade como um todo único, mas provoca também movimentos de oposição de caráter reacionário. $\bigcirc$ fascismo ganhou terreno em muitos países, inclusive no Brasil. A luta pela hegemonia intensifica os conflitos entre as nações imperialistas e aumenta a possibilidade de confrontos militares de grande escala. As duas guerras mundiais do século XX estabeleceram patamares de destruição e violência que abalaram nossa crença em valores humanistas e culturais. A segunda guerra, sobretudo, colocou o ser humano diante de situações absurdas: por um lado, a perversão do Holocausto e dos genocídios perpetrados contra comunidades, grupos étnicos e religiosos; por outro lado, o apocalipse da bomba atômica com o extermínio em massa de forma cega e indiscriminada. A realidade do Holocausto e da bomba atômica nos trouxeram a consciência de que a razão e a inteligência não são suficientes para nos livrar do perigo da barbárie. Não só podemos utilizar a nossa inteligência para perseguir e matar seres humanos, como fizemos sistematicamente em Auschwitz e indiscriminadamente em Hiroshima, como também empregar a razão, o aparelho estatal e os avanços da tecnologia para conseguir esses objetivos.

filósofo checo-brasileiro Vilém Flusser (1920-1991) cunhou o conceito de pós-história para escancarar o sentimento de absurdo desencadeado por esses eventos do século XX (FLUSSER, 1983a). O absurdo deriva da racionalização da vida, da sociedade e da cultura, que se confunde com a própria noção de progresso histórico, e que constituiu o grande sintoma da nossa crise civilizatória. Os modelos inaugurados com os eventos de Auschwitz e Hiroshima resultam da nossa crença em valores civilizatórios, que se revelam incapazes de nos livrar do espectro da ignorância e da alienação. Auschwitz e Hiroshima não foram acidentes de percurso, e sim protótipos do aparelhamento 
pós-histórico, político, administrativo e científico, que são impulsionados pelo desenvolvimento da tecnologia. As imagens técnicas, as mídias de comunicação de massa, o computador, a cibernética e inteligência artificial, são produtos de um processo tecnológico que afeta e transforma nosso espaço existencial. Vivemos um esgotamento de processos históricos, que minam valores civilizatório como a democracia e os direitos humanos. Uma idolatria de signos substitui o mundo real por simulações do mundo, que impulsionam vários tipos de fanatismos políticos, religiosos e cientificistas. A ascensão de ideias totalitárias e do fascismo, neste início do século XXI, são fenômenos que apontam para a magicização da vida, um processo que elimina a consciência história e implanta o poder alienador dos aparelhos técnicos e inteligências artificias, com a consequente crença mitológica na capacidade desses dispositivos.

Essas questões preliminares nos permitem introduzir algumas ideias sobre a evolução e a consciência humana. $\bigcirc$ grande místico e pensador contemporâneo indiano Sadhguru (2018), ao ser indagado sobre quem, na sua opinião, contribuiu mais efetivamente para o desenvolvimento da consciência humana no Ocidente, respondeu sem hesitar: o biólogo Charles Darwin. Por que um biólogo e não, por exemplo, um filósofo? Porque, disse Sadhguru, Darwin foi o primeiro cientista ocidental que elaborou a possibilidade da evolução, a ideia de que a vida pode mover-se de uma dimensão da existência para uma outra. Segundo a teoria da evolução, que Darwin expôs há um século e meio atrás, as primeiras formas de vida foram aquáticas, depois tornaram-se anfibias e finalmente terrestres. Pouco a pouco, apareceram as primeiras formas hibridas de vida, meio animais e meio humanos, que se transformaram nos primeiros protótipos de seres humanos. Os impulsos e emoções dominavam a vida desses primeiros humanoides. Posteriormente, eles aprenderam a controlar seus instintos e emoções, e cresceram de forma mais estável e equilibrada. No estágio seguinte, aprenderam a transformar os instintos e emoções primais em graça e extase. E finalmente, transcenderam o mundo dos impulsos e emoções inconscientes e se tornaram seres filosóficos e espirituais. $\bigcirc$ conceito de espiritualidade deve ser entendido aqui não como a expressão de uma fé - que dá origem a uma religião - mas no sentido científico: espiritualidade não como religião, e sim como ciência; espiritualidade como ferramenta e não como princípio, espiritualidade como dispositivo e não como dogma (SADHCURU 2018, pp.50-1).

\section{0}

REV. TULHA, RIBEIRÃO PRETO, v. 5, n. 2, pp. 107-132, jul.-dez. 2019 
A ideia central do conceito de espiritualidade que aqui propomos é de que nem tudo pode ser entendido logicamente. $\bigcirc$ filósofo austríaco Wittgenstein cunhou uma frase que ficou famosa na história da filosofia: "O que não se pode falar, deve-se calar" (UITTCENSTEIN, 1974, p.89; 2003, p. 11 1). Esta frase é a última proposição do Tratactus Logico Philosophicus $(1974,2003)$ livro que Uittgenstein escreveu durante a Primeira Guerra Mundial, quando servia no exército austríaco. Partindo do ponto de vista de que os conhecimentos filosófico e científico só podiam ser expressos em termos lógicos, Wittgenstein quis desenvolver no Tratactus uma compreensão lógica do mundo e dos limites do mundo. Mas chegou à conclusão de que isso não era viável, pois a lógica é insuficiente para compreender o mundo. A ideia central e revolucionária do Tratactus é de que o objetivo da filosofia é definir os limites entre o que pode ser dito e o que pode ser mostrado. $O$ que pode ser dito é o que pode ser expresso através da linguagem lógico-científica. $\bigcirc$ que deve ser mostrado é o que está excluído da objetividade consistente com os sistemas lógicos. Na parte final do Tratactus, Wittgenstein (1974, p.89; 2003, p.11 1) chega à seguinte conclusão: "Há de fato o inexprimível, o que se mostra; isto é o místico". Portanto, o misticismo não é algo esdrúxulo, mas uma constatação de nossa insuficiência como seres racionais para compreender o mundo como um todo.

Wittgenstein elaborou no Tratactus uma concepção original de ética. A ética é um discurso da existência humana, que transcende o mundo lógico e fatual. A ética tem como principal objetivo dar um sentido ao mundo. Para Wittgenstein, ética e estética são uma mesma e única coisa. A ética e a estética se opõem à lógica, no sentido de que a lógica é um espelho do mundo, enquanto a ética e a estética estão fora do mundo. Em oposição à lógica, a ética não revela a estrutura do mundo. A ética e estética são transcendentais, elas não descrevem fatos, mas simplesmente os mostram. Portanto, a ética e a estética pertencem ao domínio do místico, daquilo que não pode ser dito, mas só mostrado.

A atitude estética, assim como a experiência ética, pertence à esfera do transcendental. A experiência estética é a observação do mundo como um todo limitado do "exterior" por meio de um único objeto completo em si mesmo: a obra de arte. Para entender a obra de arte, precisamos primeiro separá-la de seu ambiente. Quem ouve música em uma sala de concertos, em casa, ou usando um aparelho celular, tem primeiro que isolar a música do ruído ambiente. Depois disso, o mundo se torna o mundo da música, o ruido ambiente desaparece

\section{1}

REV. TULHA, RIBEIRÃO PRETO, v. 5, n. 2, pp. 107-132, jul.-dez. 2019 
e a música ocupa todo o espaço. A música se torna o próprio mundo.

É esta capacidade da obra de arte de ver o mundo como um todo através de um espaço finito e limitado - a obra de arte - que cria a experiência estética. A obra de arte é verdadeira, independentemente de sua relação com o mundo. Transmite uma experiência que é ao mesmo tempo lógica, ética e estética. Portanto, de acordo com Wittgenstein, a arte tem uma missão mística, especialmente a música. A arte expressa - que a linguagem ordinária - lógico científica - não é capaz de expressar; ou seja aquilo que não pode ser dito, mas apenas mostrado, como diz o último parágrafo do Tractatus.

Por que é tão importante preocupar-se com a consciência humana? Por que insistimos nessa questão, que aparentemente foge à nossa concepção de mundo, lógica e racional, que direciona o nosso trabalho na universidade? Como resposta, gostaria de citar mais uma vez o místico Sadhguru (2018), que sugere o seguinte: dispomos das ferramentas e tecnologias poderosas, que podem ser usadas de forma positiva ou negativa; podem tanto fazer deste mundo um paraíso, como transformá-lo num inferno, ou mesmo destruí-lo por completo. Em outras palavras, atingimos um ponto em que, se não elevarmos a consciência humana, nossa inteligência e nossa capacidade intelectual vão trabalhar contra nós. Estamos no limiar de um processo rápido de autossabotagem, motivado pelo desenvolvimento tecnológico e a lógica de exploração desenfreada do capitalismo. $\bigcirc$ problema não é propriamente o intelecto, pois não é nenhum erro usar o intelecto; o problema é o fato de que o intelecto assumiu importância desproporcional. Quando o intelecto passa a se identificar com categorias discriminatórias tais como gênero, classe, cultura ou raça, ele perde então a sua utilidade enquanto ferramenta. A principal característica do intelecto é analisar, destrinchar e separar as coisas. $\bigcirc$ intelecto divide. E assim ele se opõe à consciência, cuja principal qualidade é a união e a inclusão. É a consciência que nos permite conectar com universo. Sem esta conexão tornamo-nos egoístas e esquizofrênicos. Por isso, se não desenvolvermos a experiência da consciência, o intelecto passará somente a dividir e acabará por destruir o mundo (SADHCURU, 2018, pp.55-57).

Após essa introdução, passarei em seguida à segunda parte do texto onde apresentarei alguns exemplos da minha pesquisa em composição musical e fenomenologia. Mas antes de iniciar a exposição propriamente dita, gostaria de abordar a questão do papel da universidade no processo de conhecimento. A função da universidade

\section{2}

REV. TULHA, RIBEIRÃO PRETO, v. 5, n. 2, pp. 107-132, jul.-dez. 2019 
é gerar "conhecimento". O conhecimento é acumulação intelectual, é informação colhida e processada em etapas, pedaço por pedaço, num processo de acumulação. Em oposição ao conhecimento, temos também o conceito de "entendimento". Como entender essa diferença? Por exemplo, se pensarmos numa flor, a dimensão do conhecimento é o saber sobre a química e a biologia da flor e também a experiência do extase da sua fragrância. Mas se nós nos tornarmos a própria fragrância da flor, isto seria o entendimento. $\bigcirc$ entendimento não é nem intelectual e nem acumulativo. É uma experiência cem por cento viva, que unifica o observador com o objeto da observação. É uma experiência "mística", tal como sugere Wittgenstein, que vai além das leis da física natural e abre caminho para um processo de autotransformação do ser. A universidade é um ambiente privilegiado para observar conexões interdisciplinares entre campos e disciplinas artísticas e as interseções entre arte, tecnologia e sociedade. $\bigcirc$ papel da universidade não é apenas interpretar e disseminar o conhecimento científico e humanístico, mas também abraçar a diversidade cultural, oferecendo múltiplas perspectivas para o avanço do pensamento crítico e promover o entendimento.

\section{Pesquisa em composição: Oratório digital A Geladeira}

Para ilustrar a minha pesquisa no campo da composição, gostaria de abordar alguns aspectos da minha obra A Celadeira (2004), oratório digital para dois cantores (meio soprano e barítono), conjunto instrumental (violino, viola, violoncelo, piano e percussão), sons eletrônicos e projeção visual interativa. Escolhi esta obra porque ela aborda uma questão que considero importantíssima no atual quadro político brasileiro. A Celadeira é uma composição que tematiza a tortura que sofri em 1971, aos 17 anos de idade, durante a ditadura militar brasileira. Encomendada pelo Centro Cultural São Paulo (CCSP) e pelo Núcleo Hespérides, a obra foi estreada no dia 8 de abril de 2014 num evento sobre os 50 anos do golpe militar de 1964'. A geladeira era um cubículo especialmente concebido e equipados para torturar por meio de som. Era um ambiente especialmente desenhando para se ter uma experiência acústica destrutiva, tanto do ponto de vista físico

\footnotetext{
I $\bigcirc$ vídeo documentando a estreia de A Geladeira está disponivel no meu site: <https:// www.paulocchagas.com/works-reader/a-geladeira-the-refrigerator-20 / 4.html>.
}

\section{3}

REV. TULHA, RIBEIRÃO PRETO, v. 5, n. 2, pp. 107-132, jul.-dez. 2019 
quando mental. Muitos anos depois, eu descrevi esta experiência da seguinte maneira:

Fui preso por causa da minha participação em grupos de oposição armada ao regime militar. Chegando na prisão militar, fui colocado na "geladeira", uma pequena sala, acusticamente isolada, e completamente escura e fria. Vários sons e ruídos eram projetados dos altofalantes, escondidos atrás das paredes. Incessantemente, a sons eletrônicos encheram o espaço escuro e tomaram de assalto o meu corpo por três longos dias. Depois de um certo tempo, perdi completamente a consciência. Essa tortura auditiva e acústica era então um desenvolvimento recente, substituindo parcialmente os métodos tradicionais de coerção física, que mataram milhares de pessoas nas prisões da América Latina entre as décadas de 1960 e 1990. Os sons feriam o corpo sem deixar vestígios visiveis. ambiente imersivo da cabine de tortura, acusticamente isolada e privada de luz, ressoa na minha memória como - ambiente perfeito para experimentar o poder da incorporação de som (CHACAS, 2006, p. 120-1).

De fato, ser torturado como prisioneiro político foi uma experiência absurda. Isto aconteceu num momento em que começava a me interessar pela música. Pouco depois, comecei a estudar seriamente música. Depois de formar-me em composição pela Universidade de São Paulo (1979), viajei para a Europa para realizar um doutorado em Musicologia com o compositor Henry Pousseur em Liège, Bélgica, e estudar composição eletroacústica na Academia de Música de Colônia, Alemanha. Parece ser um paradoxo que eu tenha me dedicado à música eletrônica, tendo extraído o seu potencial artístico do ruído: a música eletroacústica estendeu a consciência do ruído à experiência musical como um todo. $O$ sentimento do absurdo emerge do papel ambíguo do ruído, o qual é ao mesmo tempo um instrumento de pressão política e uma matéria de criação subversiva. Como afirma o sociólogo francês Jacques Jacques Attali (1985, p.6), o "ruido é a fonte do propósito e do poder". O ruido representa desordem e a música é uma ferramenta usada para racionalizar o ruído e exercer pressão política, a fim de consolidar uma sociedade. Attali descreve a evolução musical através da dialética entre a música e o ruido. A música controla o ruído, mas ao mesmo tempo dá à luz a outras formas de ruído que se transformam

\section{4}

REV. TULHA, RIBEIRÃO PRETO, v. 5, n. 2, pp. 107-132, jul.-dez. 2019 
em música. Essas formas musicais, quando estabelecidas, fazem aparecer outras formas de ruido, que se transformam em música e assim por diante. $\bigcirc$ ruído é violência absurda e a música é a revolta absurda, "um confronto permanente do homem com sua própria obscuridade", como afirmou o filósofo Albert Camus (1955, pp.4 1-42). Ouvir música é aceitar a presença de ruído nas nossas vidas: "é ouvir todos os ruídos, percebendo que sua apropriação e controle são um reflexo do poder, que é essencialmente político" (ATTALI, 1985, p.6).

Durante mais de 20 anos os brasileiros viveram em um estado de cegueira coletiva, aprendendo a sobreviver sob o regime brutal da ditadura militar, e desenvolvendo mecanismos para escapar à opressão, ao medo e à violência. No entanto, a ditadura militar não foi um incidente isolado na história do Brasil; a cegueira coletiva retornou com toda força, a partir do golpe parlamentar de 2016 que levou à ascensão da extrema-direita e do autoritarismo neofascista. A recrudescência do fascismo é um fenômeno global da fase extrema do desenvolvimento do capitalismo no início do século XXI. Atualmente, passamos por uma mudança dramática dos nossos sentimentos existenciais, impulsionada pela tecnologia digital. As máquinas digitais de informação e comunicação tomam conta do nosso corpo e desterritorializam nossas funções cognitivas, afetando a nossa experiência sensorial - auditiva, visual, espacial e tátil - transformando nossas formas de vida e nossos relacionamentos. Entretanto, a tecnologia cria uma nova ambiguidade: por um lado, suscita uma nova liberdade baseada no diálogo em rede (por exemplo, as mídias sociais), mas por outro lado, revela um novo potencial de reforçar as tendências autoritárias de controle individual e coletivo. Este é o paradoxo da tecnologia digital, com a qual convivemos.

libreto de A Celadeira - obra de aproximadamente 40 minutos de duração - propõe uma narrativa de planos superpostos, que oferecem perspectivas múltiplas para observar a minha experiência pessoal da tortura e a realidade da tortura em geral. A tortura é associada à escuridão da ignorância, à dor e ao sofrimento; a "geladeira" é apresentada como uma máquina de tortura que atua na logística de violência e crueldade da sociedade. A obra distanciase explicitamente de uma interpretação política da tortura, como por exemplo denunciar a tortura como uma forma de opressão e abuso de poder, ou chamando a atenção para a tortura no contexto da ditadura militar brasileira. Além de reconhecer a realidade desumana

\section{5}

REV. TULHA, RIBEIRÃO PRETO, v. 5, n. 2, pp. 107-132, jul.-dez. 2019 
e degradante da tortura, A Geladeira reflete sobre a minha própria evolução como ser humano. Mais do que uma ação política, a obra propõe um movimento de transcendência, uma aspiração de elevação com o objetivo de iluminar a escuridão e superar a ignorância.

A Celadeira resgata memórias da tortura à qual fui submetido - impressões, situações, emoções e sentimentos - mas, ao mesmo tempo convida-nos a olhar para a realidade da tortura que existe no mundo fora da geladeira. Tortura não é um privilégio de ditaduras ou regimes opressores, não é algo praticado exclusivamente por pessoas execráveis. A crueldade da tortura não ocorre apenas em situações extremas, é algo absolutamente corriqueiro, por exemplo, nas prisões brasileiras, e é também uma ferramenta do poder imperialista, como por exemplo a tortura praticada pelas forças militares e os serviços de inteligência norte-americanos contra os chamados "terroristas" internacionais. A tortura física, a tortura psicológica e outras formas de tortura foram incorporadas "à banalidade do mal", para usar uma expressão introduzida por Hannah Arendt ( 1993) no seu estudo sobre o julgamento do burocrata nazista Adolph Eichmann. A tortura não é um ato isolado; é algo que existe dentro de nós, uma característica universal da raça humana, e que está relacionada a tendências egoístas. Precisamos de um movimento em grande escala, uma aspiração transcendente para transformar a nossa consciência e natureza, libertar-nos da escuridão da ignorância, inércia, obscuridade, confusão e desordem. A barbárie da tortura não é a escuridão de nossa origem como ser vital, mas um estágio intermediário da evolução humana. $\bigcirc$ caminho que proponho na obra A Geladeira é uma trajetória de sacrifício ascendente, da ignorância para a transcendência do inefável. As oito cenas do oratório digital representam diferentes etapas desta jornada. Eis uma síntese da estrutura formal da obra:

Prólogo: Depoimento pessoal

Cena 1: $\quad$ Introdução: a escuridão da ignorância

Cena 2: $\quad$ A eletricidade: A máquina de meter medo

Cena 3: $\quad$ Os ruídos: imersão nas vibrações caóticas

\section{6}

REV. TULHA, RIBEIRÃO PRETO, v. 5, n. 2, pp. 107-132, jul.-dez. 2019 


$\begin{array}{ll}\text { Cena 4: } & \text { O frio: sopro da morte } \\ \text { Cena 5: } & \text { A culpa: testemunhando a tortura de } \\ \text { Cena 6: } & \text { A dor: O sentimento da finitude } \\ \text { Cena 7: } & \text { As formas de tortura: a tortura invisível } \\ \text { Cena 8: } & \text { A paz: música que vive não-cantada }\end{array}$

\section{Prólogo: Depoimento pessoal sobre a tortura - peça radiofônica}

Em 1971, foi no mês de junho, eu tinha dezessete anos, fiz dezoito anos no mês de agosto. Foram me buscar na minha casa, eu estava dormindo, fui levado para a Polícia do Exército, o DOI, que corresponde ao DOI-CODE aqui em São Paulo, mas era no Rio de Janeiro, na Rua Barão de Mesquita, na Tijuca. E eu fui levado lá, e fui colocado nessa geladeira, que era uma coisa nova. Eu sei que era nova porque estava cheirando a pintura. Era um cubículo bastante pequeno, devia ter uns dois metros por dois metros mais ou menos, escuro, forrado de Eucatex, com ar condicionado, e era bastante frio. Eu fiquei lá um bom tempo, que acredito ser uns três dias. A particularidade dessa geladeira é que existiam alto-falantes que estavam embutidos atrás das paredes, e existia uma comunicação entre quem estava lá dentro e os torturadores. Então os torturadores estavam do lado de fora e eles ficavam conversando com você e fazendo ameaças, ficavam fazendo brincadeiras, bem grotescas mesmo. Então, a partir de um certo momento, começaram a tocar sons, ruídos. Isso em 1971, [quando] a técnica de gravação era uma coisa ainda muito incipiente, não existiam esses ruidos que a gente tem hoje. Mas existia, por exemplo, uma coisa que me lembro bem, [que] era esse ruído de receptor de rádio AM, quando você mudava de estação, sintonizava - poucas pessoas hoje conhecem isso não é? Antigamente você tinha esse ruído [fonemas sibilantes] quando você estava mudando de uma estação a outra, sintonizando - então

\section{7}

REV. TULHA, RIBEIRÃO PRETO, v. 5, n. 2, pp. 107-132, jul.-dez. 2019 
esse era um dos ruídos principais: querer sintonizar um rádio que não sintonizava e ficava nessa zoeira. Isso era um ruído bastante grande, que é o ruído do éter, as ondas de rádio que vivem no éter. Os transístores, os receptores de rádio decodificam essas modulações: AM que é modulação de amplitude e FM que é modulação de frequência. Então AM vai fazendo [fonemas imitando modulações de amplitude], FM faz [fonemas imitando modulações de frequência]. Então isso aí era muito alto. Imagina que você está num lugar completamente isolado acusticamente e você está submetido a esses ruídos de rádio que são fortíssimos. E fora isso tinha outros ruídos: ruído de motocicleta, ruído de motor, ruído de serra, e coisas que eles tinham lá e eles ficavam [risadas], ficavam se divertindo, ficavam dando risada e fazendo esses ruídos. Mas era muito alto, muito alto; alto a ponto de realmente doer. Porque se você for submetido a sons, a vibrações sonoras, todo o seu corpo pode se desestruturar. Você não só fica surdo como fica num estado que impacta e transforma a sua consciência. Então essa tortura sonora era uma coisa que foi bastante sofisticada e que pouca gente conhece. A particularidade disso é que não deixa a menor marca. Quer dizer, o som tem a particularidade de invadir o seu corpo, de se apossar do seu corpo e colocar o corpo em movimento, e se você usar ruídos os movimentos vão ser caóticos. Você começa a ser desestruturado fisicamente e psiquicamente (CHACAS, 2017, pp. 336-337).

\section{Música eletroacústica: a degradação do tiro revólver}

Depois do prólogo, o oratório digital começa com uma música eletrônica acusmática de aproximadamente 5 minutos. $\bigcirc$ material da música eletrônica é constituído por apenas um único som: um tiro de revolver. Este som de base - a detonação de uma bala - tem uma duração muito curta, apenas 900 ms (milissegundos). É um som percussivo, explosivo, com um ataque breve e fortíssimo e um decaimento rápido da intensidade. A partir de 600 ms resta um resíduo sonoro que vai diminuindo gradativamente até desaparecer por completo. $\bigcirc$ envelope sonoro da detonação tem uma forma que evoca a ponta de uma flecha (Figura 1). Assim como a flecha, a bala de revolver é um objeto contundente que penetra no corpo a fim de causar danos ou mesmo 
destruí-lo. $\bigcirc$ tiro de revólver é um som banal, que estamos acostumados a ouvir nos filmes de guerra, bangue-bangues, policiais e também videogames. O ruido ressoante das armas de fogos é evocado, também, nas músicas eletrônicas - tanto eruditas quanto populares - com seus ataques explosivos e penetrantes e os ritmos obsessivos que incitam a violência. A detonação de um tiro e seus simulacros eletrônicos já se incorporaram ao cotidiano da nossa paisagem sonora e audiovisual.

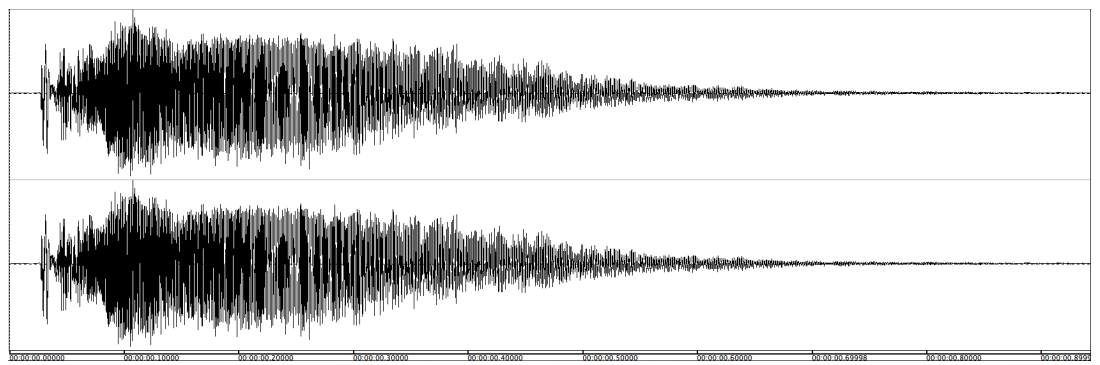

Figura 1: Representação visual do som do tiro de revólver

A composição da música eletrônica foi criada a partir de expansões temporais do tiro do resolver - o método popularizado como time stretching. Trata-se de um procedimento de análise e síntese, uma aplicação musical da teoria matemática de Fourier, segundo a qual o som é decomposto em uma série de sinais periódicos sinusoidais e recomposto de acordo com o fator de expansão. A "qualidade" do som transformado depende de vários fatores, que são os parâmetros de análise e síntese. No caso específico dessa composição eletrônica, não busquei a qualidade e sim a degradação do sinal: os parâmetros foram ajustados de forma que a expansão temporal do som do tiro de revolver produzisse "artefatos" digitais para "deturpar" e "corromper" o timbre.

Essa forma de degradação sonora foi produzida intencionalmente. Ela representa uma metáfora da tortura como aviltamento da dignidade do indivíduo, uma forma de perversão da condição humana e expressão da sordidez que motiva o ato de torturar. O tiro do revólver evoca a violência, o ato de matar o ser humano com um só movimento, o gesto de puxar o gatilho. Entretanto, do ponto de vista do timbre, o som do tiro possui a qualidade do ruído, que é um 
som rico, onde todas as frequências audiveis coexistem simultaneamente, de forma virtual. Os artefatos gerados nos processos de expansão temporal alteraram a qualidade do timbre do tiro, destruíram sua riqueza, transformaram o espectro sonoro do ruído em um som monótono, desprovido de harmônicos. A bala detonada pelo cano do revólver foi aviltada, depravada e corrompida. $O$ ruído do tiro foi destituído de sua qualidade de som percussivo e explosivo, tornou-se um resíduo de sons sinusoidais, monótonos, como um ruído de fundo amorfo e insensível.

A tortura, enquanto corrupção gradual da integridade física e moral, é um processo repetitivo. As expansões temporais do som do tiro de revolver evocam também as modulações ruidosas dos receptores analógicos de rádio quando se tenta sintonizar uma estação. Foram estes sons que ficaram gravados na minha memória. $\bigcirc$ ruído do receptor de rádio é o símbolo da tortura acústica à qual fui submetido na geladeira. A música eletrônica antecipa assim um dos elementos temáticos da composição vocal e instrumental - a "estação que nunca é sintonizada" - que é tratado como um leitmotiv. Por outro lado, a monotonia eletrônica provoca também uma irritação, que é reforçada pelas repetições e a predominância de frequências agudas

Como mostra a figura 2, a música começa com a primeira expansão temporal do tiro, de baixa amplitude, e duração de 1:28" (0"1:28"); segue-se uma segunda expansão temporal, com mais intensidade e duração de 2:50" ( 1:28" - 4:18"); e, finalmente, uma terceira expansão, mais curta e bem mais discreta em termos de amplitude, que funciona como espécie de suspiro conclusivo (coda), com duração de 47" (4:18"5:05"). Assim como a monotonia das frequências agudas machuca os ouvidos, a repetição tem um efeito irritante e mesmo angustiante, sobretudo a partir do decaimento da segunda expansão temporal, que é um longo processo e não traz nenhuma novidade. $\bigcirc$ enfado, o tédio e o incômodo são aqui intencionais. A forma musical imerge o ouvinte num ambiente acústico desagradável - a câmara de tortura sonora - com uma intenção explícita de causar mal-estar. 


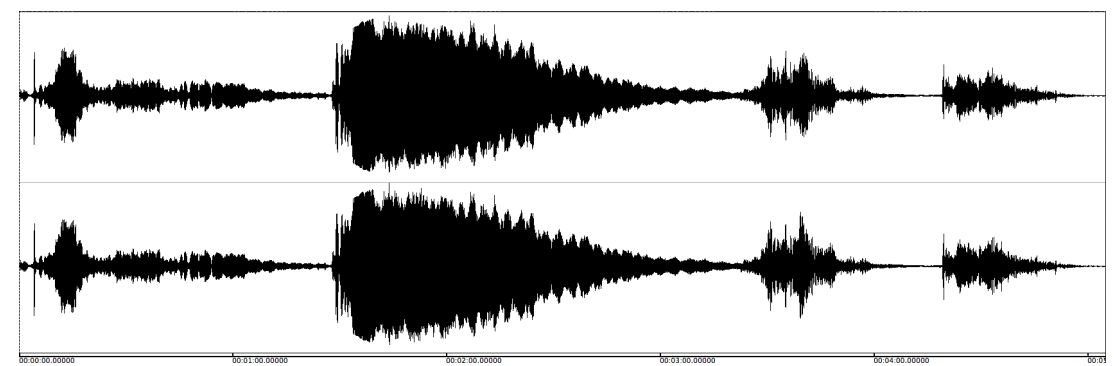

Figura 2: Representação visual da música eletrônica

\section{O mito de Sísifo: o herói do absurdo}

$\bigcirc$ filósofo e escritor francês Albert Camus, no livro $\bigcirc$ Mito de Sísifo dá a seguinte definição do absurdo: "O absurdo nasce desse confronto entre o apelo humano e o silêncio despropositado do mundo" (CAMUS, 1955, p.24). Na filosofia de Camus, o absurdo é um conflito que surge da relação entre a humanidade e o mundo, a partir da "impossibilidade de constituir o mundo como uma unidade" (CAMUS, 1955, p.9). A nostalgia da unidade e do absoluto, segundo ele, é "o impulso essencial do drama humano" (1955, 17). O absurdo "é esse divórcio entre o espírito que deseja e o mundo que frustra, minha nostalgia por uma unidade, esse universo fragmentado e a contradição que os une" (CAMUS, 1955, p.39).

Para Camus, Sísifo é o herói absurdo, o personagem mítico que simboliza o absurdo tanto através de sua paixão quanto através do seu sofrimento. "Os deuses tinham condenado Sísifo a rolar um rochedo incessantemente até o cume de uma montanha, de onde a pedra caía de novo por seu próprio peso. Eles tinham pensado, com as suas razões, que não existe punição mais terrivel do que o trabalho inútil e sem esperança." (CAMUS, 1955, p.85). Ele foi punido por se atrever a desafiar a morte e desprezar assim os deuses, e também por sua paixão pela vida. Segundo Camus (1955, p.86), o destino de Sísifo, seu trabalho inútil e sem esperança, não é diferente de os trabalhadores de hoje que passam todos os dias de suas vidas cumprindo as mesmas tarefas. Sísifo, proletário dos deuses, impotente e revoltado, simboliza a atitude de revolta consciente: "ele conhece toda a extensão de sua condição miserável” (CAMUS, 1955, p. 86), mas, em vez de desespero, 
ele realiza seu trabalho com alegria. Assim, Camus nos surpreende com a seguinte conclusão: "É preciso imaginar Sísifo feliz" (CAMUS, 1955, p.88). Felicidade e o absurdo são inseparáveis: a vida do homem absurdo, quando contempla sua aflição, é preenchida por uma alegria silenciosa.

\section{Pesquisa em fenomenologia do som}

Passemos agora ao próximo tema do texto que diz respeito à minha pesquisa sobre fenomenologia do som. Este trabalho insere-se na disciplina de "estudos sonoros", um campo amplo de conhecimento interdisciplinar que se expandiu nas últimas décadas. Os estudos sonoros investigam aspectos culturais, sociais, políticos e filosóficos relacionados ao som, à escuta, às arquiteturas sonoras e mídias auditivas, assim como as práticas de produção sonora que incluem tanto a música como as novas criações da chamada "arte sonora". Os estudos sonoros examinam também como as percepções e tecnologias do som emergem nos contextos históricos, culturais e sociais e o impacto do som sobre o meio ambiente.

que é som e como nos expressamos através dos mundos sonoros? Para responder a essa pergunta, parto de uma abordagem fenomenológica do som, cuja origem é a Fenomenologia da Consciência Interna do Tempo de Husserl (1966; 1991). A consciência temporal, segundo Husserl, é o nível mais elementar da percepção e da experiência, que nos permite identificar objetos, sensações, emoções e o fluxo da consciência que estabelece a continuidade temporal. Husserl explica a consciência interna do tempo através de várias metáforas musicais. Por exemplo, a metáfora da melodia. Como ouvimos uma melodia? 0 primeiro nível de audição é a identificação de cada som da melodia como um objeto temporal; ou seja, ouvimos a duração de cada som que identificamos como o presente. Porém este presente não é um ponto isolado, mas um campo estendido de simultaneidade que inclui tanto o passado como o futuro. Quando uma melodia é cantada ou tocada por um instrumento (ou um som eletrônico), os sons individuais não desaparecem, mas reverberam no fluxo da consciência interior do tempo. Ouvimos não apenas os sons do presente, mas também os sons do passado que retemos na nossa memória e os sons do futuro que são projeções de nossas expectativas. 
A segunda resposta à pergunta - o que é som e como nos expressamos através dos mundos sonoros - está relacionada ao conceito de verdade, inspirada da filosofia de Heidegger. Em A Origem da Obra de Arte, Heidegger (1950, 1993) elabora a visão da verdade como a essência da arte. A verdade da arte não é uma questão de beleza ou precisão de representação, mas consiste em nos dar uma visão do mundo que mostra como as coisas realmente são. Assim, a arte nos ajuda a desenvolver uma nova compreensão que vai além da pura experiência estética. Heidegger (1993) evoca o termo "desvelamento" para definir a essência da verdade. As obras de arte operam como descrições fenomenológicas que iluminam um mundo, fornecendo uma visão de dentro. Em outras palavras, as obras de arte revelam o ser $e$ as entidades, ajudando-nos a ver o que as coisas realmente são. A obra de arte fornece um modo coerente de ser - um estilo - que dá luz a um mundo e, ao mesmo tempo, incorpora o processo de luta que faz as coisas aparecem no mundo. A arte é o estabelecimento da verdade; cada obra de arte, afirma Heidegger, "nos tira de nossa rotina banal e nos mergulha no que é revelado pela obra, trazendo à tona nossa essência e nos obrigando a tomar posição como ser." (HEIDECCER, 1993, p. 199).

Na concepção de Heidegger, a arte é um trabalho de configuração da verdade - um modo distinto através do qual a verdade surge e se torna histórica. Este ponto de vista implica em considerar que a arte é contextual e determinada pela cultura. A arte articula um "estilo" ou uma cultura preservando criativamente a verdade na obra de arte. Esta noção de estilo de Heidegger pode ser comparada ao que Wittgenstein (2009) chama de "forma de vida". Ao criar um estilo dentro de uma cultura, a arte se torna uma forma de vida. A música tem um papel privilegiado na filosofia de Wittgenstein. Ele considera a música como uma arte mais sofisticada, pois fornece uma superfície simples - o som - que oculta uma complexidade infinita, a qual tentamos entender usando a linguagem².

A questão da "compreensão" desempenha um papel central na filosofia de Wittgenstein. Compreender não é um processo de ir para dentro, mas de olhar para a superfície de nossa prática, que

2 A expressão "forma de vida" tem um papel importante na filosofia de Wittgenstein depois do Tratactus. Há inúmeras reflexões sobre "forma de vida" nas Investigações Filosóficas (UITTCENSTEIN, 2013). A respeito de "forma de vida" no contexto de observações sobre a música ver CHACAS (2014; 2015). 
está ligada à complexidade dos padrões que caracterizam nossa forma de vida. A filosofia de Wittgenstein usa a música como uma ferramenta para refletir sobre a compreensão da linguagem e sobre a compreensão em geral. A música - semelhante à linguagem - não é um sistema abstrato de signos que transmite algum tipo de significado, mas uma forma particular de vida que exibe estruturas determinada pelas práticas musicais. Wittgenstein nos convida a olhar para o modo como determinamos conceitos musicais, a forma como constituímos padrões regulares seguindo regras, como escolhemos seguir algumas regras e descartamos outras, como aplicamos palavras como "certo" ou "errado" para fazer julgamentos estéticos sobre música e em geral, e assim por diante (CHACAS, 2015, p.301).

\section{O paradigma eletroacústico}

Um foco importante da minha pesquisa fenomenológica do som, é o foco no chamado "paradigma eletroacústico". O conceito de paradigma emerge em referência à obra seminal de Kuhn, A Estrutura das Revoluções Cientificas (KUHN, 2012). Kuhn argumenta que o desenvolvimento da ciência é impulsionado pelo que ele chama de "paradigma". O paradigma pode ser definido como uma "matriz disciplinar", cuja função é fornecer aos cientistas um vasto reservatório de quebra-cabeças e as ferramentas para resolvê-los. A busca de um novo paradigma é impulsionada pela incapacidade do atual paradigma de resolver certos enigmas importantes que são considerados "anomalias" (KUHN, 2012, p.181). Quando a ciência perde a confiança em um paradigma para superar essas anomalias ocorre então uma revolução científica que estabelece um novo paradigma. Exemplos de paradigmas criados para resolver crises são a revolução de Copérnico, que propõe uma solução para a crise do sistema de astronomia de Ptolomev, e o paradigma de Einstein que substituiu o paradigma de Newton para tornar a eletrodinâmica compatível com um sistema de movimento.

Uma fenomenologia do som que se propõe a refletir sobre o "paradigma eletroacústico" começa com uma crítica abrangente da "crise" da tonalidade como matriz disciplinar - ou paradigma - da composição musical. A neutralização da funcionalidade tonal através das estéticas da música atonal, serial e outros tipos de organização do material sonoro, no início do século XX, estabelece uma descontinuidade harmônica através de uma miríade de "anomalias" que desestabilizam

\section{4}

REV. TULHA, RIBEIRÃO PRETO, v. 5, n. 2, pp. 107-132, jul.-dez. 2019 
e corroem o papel fundamental da harmonia na composição musical. Esta crise desencadeia respostas que levam a diferentes narrativas e complexas texturas sonoras na música de compositores como Schoenberg, Webern, Debussy, Stravinsky, Bartok, Messiaen e muitos outros. Além disso, incentiva os compositores a explorarem outros princípios construtivos de organização musical focados na realidade física dos fenômenos sonoros e enfatizando qualidades sonoras como timbre e ruído. $\bigcirc$ desenvolvimento da música concreta, da música eletrônica e da computação musical atende às exigências da sensibilidade estética centrada nesta consciência ampliada dos fenômenos sonoros que emerge na crise do paradigma acústico como campo primordial da composição musical.

movimento conhecido como musique concrète, que surge em Paris no início da década de 1950 em torno de Pierre Schaeffer, começou com experimentos envolvendo técnicas de gravação para captar sons naturais do ambiente acústico. Essa abordagem subentende o mito imanente de ouvir o som do mundo como uma fonte de criatividade musical. $\bigcirc$ fenômeno sonoro é isolado do ambiente físico e desacoplado de sua fonte material. Liberado de suas referências culturais, o som se torna uma mídia autorreferencial para compor novas formas audiveis, aproveitando-se de novas tecnologias para gravar e manipular o material acústico. Inspirando-se em conceitos da fenomenologia de Husserl (1966, 1991), a estética da música concreta desenvolve noções como objeto sonoro, evento sonoro e escuta reduzida. Essas categorias definidas através da interação de material sonoro com aparatos técnicos, especialmente o gravador, fornecem o arcabouço de abordagens analíticas e sintéticas para a composição eletroacústica.

Enquanto a musique concrete cultivava o mito de escutar o som do mundo, a elektronische Musik, associada ao estúdio de música eletrônica da rádio de Colônia, preocupava-se com a criação de sons sintéticos, cujos modelos não são encontrados na natureza nem possuem as qualidades dos sons instrumentais e vocais. A perspectiva adotada pelos compositores de elektronische Musik, particularmente Karlheinz Stockhausen, era inventar novos sons construidos a partir de elementos simples, os sons sintéticos produzidos por dois aparelhos: o oscilador de onda senoidal e o gerador de ruído. Esses aparelhos realizam funções revolucionárias carregadas de significado simbólico. A onda senoidal é uma construção matemática que representa a pureza de um único movimento harmônico, como um pêndulo balançando continuamente no 
ar. $\bigcirc$ ruído branco também é uma construção matemática, mas, em oposição à onda senoidal, simboliza a riqueza estatística de todas as vibrações possiveis que ocorrem aleatoriamente no espectro sonoro. Desde o início, a elektronische Musik valorizou os processos de controle do material sonoro a fim de desenvolver sistemas coerentes de timbres, que funcionam como base da composição musical.

paradigma da música eletroacústica representa um novo tipo de consciência da relação entre música e tecnologia, que foi acelerada pela popularização do computador e pelo desenvolvimento da tecnologia digital de informação e comunicação. A música da era digital não se restringe mais aos corpos que produzem som ou manipulam instrumentos, mas estendem-se às máquinas, sistemas inteligentes e universos virtuais. A música adquire assim um caráter fluido através da multiplicidade de conexões e dos múltiplos contextos nos quais ela pode ser inserida e expressa (CHACAS, 2014, p. 104). A conectividade digital acelera o processo de diferenciação que ocorre na arte e na sociedade como um todo. A diferenciação é o principal argumento da teoria da arte como sistema social elaborada pelo sociólogo alemão Niklas Luhman (LUHMANN, 1997, 2000). A exploração do som como um objeto significativo, técnico e cultural, cria novos campos de atividade artística - por exemplo o desenho sonoro, a arte sonora, e a paisagem sonora - e também desdobra novas conexões interdisciplinares entre o som, a performance, as mídias visuais, o corpo e o espaço.

$\bigcirc$ paradigma eletroacústico pode ser entendido, por um lado, no contexto histórico, como uma continuidade natural das técnicas de composição da música acústica; por exemplo, os métodos de composição de timbre que surgiram no âmbito da música serial e em outras estéticas do início do século XX. Por outro lado, a composição eletroacústica revoluciona a compreensão tradicional da música, ao valorizar o que antes era considerado "ruido" como categoria expressiva do material musical e, consequentemente, destruindo a supremacia do conceito tradicional de som musical, típico da música europeia. Como observa Pousseur, a música eletroacústica articula uma interação contínua entre os diferentes níveis de organização do som, de modo que se torna difícil "traçar um limite preciso entre a composição interna do som e níveis mais elevados de composição" (POUSSEUR, 1970, p.82). O som musical não é um objeto isolado, mas pode ser entendido apenas em um contexto de composição. Não é possível falar de fenômenos sonoros, mesmo quando isolados, sem considerar suas possibilidades composicionais. Portanto, 
a música eletroacústica articula a produção do som musical em uma atividade poética significativa de múltiplas camadas, que relaciona os níveis microscópico e macroscópico da composição sonora.

\section{A questão da tecnologia}

Uma fenomenologia crítica do conceito de aparelho é crucial para se desenvolver uma compreensão mais profunda do modo de operação do paradigma eletroacústico. $\bigcirc$ filósofo Agamben define a fase extrema do desenvolvimento capitalista em que vivemos como uma acumulação e proliferação maciças de aparelhos. (ACAMBEN, 2009, p. 145). Ele propõe uma definição expandida do conceito de aparelho, que se aplica "literalmente a qualquer coisa que possua de alguma forma a capacidade de capturar, orientar, determinar, interceptar, modelar, controlar ou proteger os gestos, comportamentos, opiniões ou discursos dos seres vivos" (ACAMBEN 2009, p. 14 ). Nesse sentido, as fábricas, prisões, escolas, hospitais, manicômios, o sistema jurídico e tudo o que se relaciona ao poder são considerados aparelhos, assim como o lápis, a escrita, literatura, filosofia, o computador, telefones celulares e até a própria linguagem, que seria o protótipo dos aparelhos. Flusser (1983, 1985, 1997, 1999,2000) preocupa-se especificamente com os aparelhos técnicos e as estruturas de comunicação, que geram as informações da sociedade cibernética. Os aparelhos técnicos, segundo ele, ativam uma ritualização de modelos sob a forma de programas, os quais atraem nossa atenção para a superfície das coisas e mantêm escondidos seus interiores. Nesse sentido, os aparelhos funcionam como verdadeiras caixas pretas, buracos negros de um universo que é inacessivel à nossa experiência. A magia programática dos aparatos técnicos, como os que produzem sons e imagens digitais, tende a eliminar o pensamento crítico, substituindo a consciência histórica por uma consciência mágica de segunda ordem que reduz a cultura ao seu mais baixo denominador. Isto vai de encontro à concepção de Heidegger, de que a tecnologia moderna mudou nosso gosto ou senso de mundo, pois tende a reduzir tudo a meros recursos, incluindo os próprios seres humanos (WRATHALL, 2005, p.101) Com o advento do aparelho, as relações de poder se movem do nivel de objetos e materiais para o nível simbólico de programas e seus modos de operação. Como argumenta Agamben, o aparelho é basicamente uma máquina de subjetivação; porém na atual fase do capitalismo, onde as sociedades se apresentam como corpos inertes de movimentos de massificação, os aparelhos não produzem mais 
sujeitos, e sim processos de de-subjetivação (ACAMBEN, 2009, p.20) As redes globais de comunicação - por exemplo as mídias sociais estabelecem conexões múltiplas e multipolares, que criam realidades ambivalentes, ao mesmo tempo libertadoras e totalitárias. Diante dessa ambiguidade, corremos o risco de sucumbir ao movimento incessante, porém sem rumo, da máquina do tecno-fascismo. Por isso, não podemos fugir à reflexão sobre como nós, seres humanos, podemos construir um espaço de criatividade que resista à programação automática e ingovernável dos aparelhos.

Para concluir este texto, gostaria de evocar mais uma vez as ideias de Heidegger sobre a arte. Na sua análise sobre a estética de Heidegger, Thomson (2015) discute o conceito de "enquadramento" que traduz a "compreensão tecnológica do ser", a qual, segundo Heidegger, é subjacente à nossa era contemporânea e tem o poder de moldá-la. (THOMSON, 2015, p.20). Heidegger acredita que o enquadramento pode conduzir a uma genuína pós-modernidade, uma era que transcende a atual tecnologização da realidade, inaugurada com o modernismo, e que trouxe a erosão nilista de todo significado intrínseco. Considerando que a verdade mais elevada da arte é o desvelamento da essência das entidades, ou seja, a revelação do ser das entidades, Heidegger expressa a esperança de que a arte poderia articular um entendimento pós-moderno no qual as entidades não são vistas como mero objetos a serem controlados ou recursos a serem otimizados. O objetivo final do pensamento de Heidegger sobre arte, como sugere Thomson $(2015,25)$, "é mostrar a importância de mover-se da experiência estética moderna focada no objeto da arte para um encontro genuinamente pós-moderno com a obra de arte, para que a arte possa assim nos ensinar como transcender a modernidade a partir do seu interior". 


\section{Referências}

ACAMBEN, Giorgio. What Is an Apparatus? and Other Essays (Meridian: Crossing Aesthetics). Transl. by D. Kishik and S. Pedatella. Stanford, CA: Stanford University Press, 2009.

ARENDT, Hannah. Eichmann in Jerusalem: A Report on the Banality of Evil. New York: Penguin Books, 1963.

ATTALI, Jacques. Noise: The Political Economy of Music. Translated by Brian Massumi. Minneapolis: University of Minnesota Press, 1985.

CAMUS, Albert. The Myth of Sisyphus and Other Essays. Translated by J. O'Brien. New York: Vintage, 1955.

Callimard, 1996 [1942].

Le Mythe de Sisyphe: Essai sur l'Absurde. Paris:

Chagas, Paulo C. "The Blindness Paradigm: The Visibility and Invisibility of the Body". Contemporary Review, 25:1/2, 1 19-30, 2006.

"Polyphony and Technology in Interdisciplinary Composition." Proceedings of the I Ith Brazilian Symposium on Computer Music, 47-58. São Paulo: IME/ECA, 2007.

Unsayable Music: Six Reflections on Musical Semiotics, Electroacoustic and Digital Music. Leuven: University of Leuven Press, 2014.

"Musical Understanding: Wittgenstein, Ethics, and Aesthetics." Music, Analysis, Experience: New Perspectives in Musical Semiotics, edited by C. Maeder and M. Reybrouck, 115-33. Leuven: Leuven University Press, 2015.

"Revolt and Ambivalence: Music, Torture and Absurdity in the Digital Oratorio The Refrigerator." Bridging People and Sound. CMMR 2016. Lecture Notes in Computer Science, vol. 10525, 
edited by M. Aramaki, R. Kronland-Martinet and S. Ystad, 331-46. New York: Springer International Publishing, 2017.

DREYFUS, Hubert. "Heidegger's Ontology of Art". In A Companion to Heidegger, edited by H. Dreyfus and M. Wrathall, 407-19. London: Blackwell, 2005.

FLUSSER, Vilém. Pós-História: Vinte Instantâneos e um Modo de Usar. São Paulo: Livraria Duas Cidades, 1983a.

Für eine Philosophie der Fotografie. Cöttingen: European Photography, 1983b.

Ins Universum der technischen Bilder. Göttingen: European Photography, 1985.

Vom Stand der Dinge: Eine kleine Philosophie des Designs. Göttingen: Steidl Verlag, 1997.

The Shape of Things: A Philosophy of Design. London: Reaktion Books, 1999.

Towards a Philosophy of Photography. Translated by A. Mathews. London: Reaction Books, 2000.

Into the Universe of Technical Images. Translated by Nancy Ann Roth. Minneapolis: University of Minnesota Press, 2011.

HEIDECGER, Martin. Holzwege. Frankfurt am Main: Vittorio Klostermann, 1950.

Basic Writings. Edited by David Farrell Krell. San Francisco: Harper Perennial, 1993.

HUSSERL, Edmund. Zur Phänomenologie des inneren Zeitbewußtseins (1893-1917). Husserliana X. Edited by R. Boehm. The Hague: M. Nijhoff, 1966. 
On the Phenomenology of the Consciousness of Internal Time (1893-1917). Translated by J. _Brough. Boston; Dordrecht: Kluwer Academic Publishers, 1991.

KUHN, Thomas. The Structure of Scientific Revolutions, $4^{\text {th }}$ ed. Chicago: University of Chicago Press, 2012.

LUHMANN, Niklas. Die Kunst der Gesellschaft. Frankfurt am Main: Suhrkamp, 1997.

Art as Social System. Translated by Eva M. Knodt. Stanford, CA: Stanford University Press, 2000.

POUSSEUR, Henri. Fragments théoriques I: sur la musique expérimentale. Brussels: Editions de l'Institut de Sociologie de l'Université Libre de Bruxelles, 1970.

THOMSON, lain. "Heidegger's Aesthetics", In The Stanford Encyclopedia of Philosophy (Fall 2015 Edition), ed. by Edward N. Zalta, 20 15. Disponivel em <https://plato.stanford.edu/archives/fall2015/entries/ heidegaer-aesthetics/>. Acesso em: 05 de outubro de 2019.

UITTCENSTEIN, Ludwig. Tractatus Logico-Philosophicus. Translated by D. F. Pears and B. F. McGuiness. London; New York: Routledge, 1974.

Logisch-philosophische Abhandlung. Tractatus logico-philosophicus. Tagebücher 1914-16. Suhrkamp: Frankfurt am Main, 2003.

P._._. Philosophische Untersuchungen. Philosophical Investigations. Translated by G. E. M. Anscombe, P. M. S. Hacker and Joachim Schulte. Rev. $4^{\text {th }}$ ed. By P. M. S. Hacker and Joachim Schulte. Oxford: WileyBlackwell, 2009.

URATHALL, Mark. How To Read Heidegger. London: Granta Publications, 2005. 


\section{Sobre o autor}

Paulo C. Chagas é Professor de Composição na Universidade da California, Riverside. Compositor brasileiro de reputação internacional com uma carreira que se estende por várias décadas, sua música desenvolve uma estética pluralista que utilizada materiais musicais de diferentes culturas, mídias acústicas, eletroacústicas e digitais, dança, vídeo e instalações audiovisuais. Chagas tem mais de 160 obras escritas para orquestra, música de câmara, música eletroacústica, audiovisual, que são executadas na Europa, Estados Unidos, Rússia e Brasil.

Chagas estudou composição na Universidade de São Paulo, no Conservatório Real de Música de Liège, Bélgica e música eletrônica na Escola Superior de Música de Colônia, Alemanha. É doutor em Musicologia pela Universidade de Liège. Entre 1980-2004 viveu na Bélgica e Alemanha; entre 1990- 1999 foi Diretor de Som do Estúdio de Música Eletrônica da Rádio URD de Colônia. Desde 2004 é Professor de Composição da Universidade da Califórnia, Riverside, EUA, onde fundou e dirige o laboratório de pesquisa EARS (Experimental Acoustics Research Studio), voltado para a pesquisa interdisciplinar em música e multimídia.

Chagas é também um prolífico autor de textos sobre música escritos em vários idiomas (inglês, alemão, português e francês) e publicados em livros e revistas internacionais. Seu mais recente livro, Unsayable Music (Leuven University Press, 2014) propões uma série de reflexões críticas e analíticas sobre a estética e a criatividade da música contemporânea abrangendo temas de semiótica musical, música eletroacústica e digital.

Paulo C. Chagas - Universidade da Califórnia, Riverside Titulação: "Full Professor"

Texto apresentado no VIII Encontro de Musicologia, USP Ribeirão Preto - 23/08/2019 